\title{
REPRESENTASI KEKUATAN, KECERDASAN, DAN CITA RASA PEREMPUAN: ANALISIS WACANA PADA FILM “THE IRON LADY”
}

\author{
Bhernadetta Pravita Wahyuningtyas \\ Marketing Communication Department, Faculty of Economic and Communication, BINUS University \\ Jln. K.H. Syahdan No. 9, Palmerah, Jakarta Barat 11480 \\ bhernadetta@gmail.com,bwahyuningtyas@binus.edu
}

\begin{abstract}
People's perception about women describes how women tend to be labelized with various drawbacks. Futhermore, many films put women as appendages to satisfy the desire of seeing the physical polish only, without portraying positive side of a woman which actually represents her personal integrity. Nevertheless, the struggle of women to prove their existence is unstoppable, such as in "The Iron Lady" movie. The movie intends to persuade women that they need to pump out the power within them to boldly express their thoughts, come out from the mutedness and show their superiority, in smart ways, woman way. Besides, the movie shows some gender imbalances in Parliament and political life which are synonymous with patriarchal ideology. The movie also shows the struggle against the suppression and mutedness of women with the feminist existentialist concept. This study used critical paradigm with Roland Barthes' semiotic discourse analysis. Research reveals how women represented in "The Iron Lady" and how symbols or values of women should be represented. Results show that women can actually defend themselves and even more after understanding the suppressions. Amid the crush and the dominance of parliamentary colleagues, Thatcher was able to align her position. Though overall ridiculed, doubted, and disbelieved her ability, she took the duty and responsibility as politician and stateswoman. Woman, who is able to oversee, maintain and nurture the country, even stronger, more resilient, and more manly than men.
\end{abstract}

Keywords: representation, movie, feminist existentialist

\begin{abstract}
ABSTRAK
Persepsi masyarakat tentang perempuan menggambarkan bagaimana perempuan cenderung disudutkan dan dilabeli dengan berbagai kelemahan. Ditambah lagi, banyak film meletakkan tokoh perempuan sebagai pelengkap semata, sebagai pemuas keinginan untuk sekadar melihat polesan fisik, tanpa mencitrakan sisi positif yang dimiliki perempuan yang justru merepresentasikan keutuhan pribadinya. Namun demikian, perjuangan perempuan untuk membuktikan eksistensinya tidaklah mudah dibendung, seperti dalam film "The Iron Lady". Film "The Iron Lady" bertujuan untuk menyadarkan perempuan bahwa perlu kekuatan yang dipompa keluar dari dalam diri untuk berani bersuara, keluar dari keterbungkaman, dan menunjukkan keunggulannya, lewat cara yang cerdas, cara perempuan. Film ini menunjukkan beberapa ketimpangan gender dalam parlemen dan kehidupan politik yang identik dengan ideologi patriarki. Di samping itu, film ini menunjukkan perjuangan perempuan yang melawan penekanan dan keterbungkamannya dengan konsepsi feminis eksistensialis. Penelitian mengungkapkan bagaimana perempuan direpresentasikan dalam film "The Iron Lady" serta bagaimana simbol atau nilai-nilai perempuan seharusnya direpresentasikan. Penelitian menggunakan paradigma kritis, dengan metode analisis wacana semiotik Roland Barthes. Hasil menunjukkan bahwa perempuan justru dapat mempertahankan diri dan justru jadi lebih diperhatikan setelah memahami ketertindasannya. Di tengah himpitan dan dominasi parlemen yang ketika itu semuanya adalah laki-laki-hanya Thatcher yang perempuan, Thatcher mampu menyejajarkan posisinya. Meskipun banyak cemoohan, keraguan, dan ketidakpercayaan akan kemampuannya sebagai seorang perempuan, ia mengemban tugas dan tanggung jawab sebagai politisi dan negarawan. Perempuan, yang mampu mengawal, menjaga dan mengasuh negara, bahkan lebih kuat, lebih tegar, dan lebih gagah daripada para pria.
\end{abstract}

Kata kunci: representasi, film, feminis eksistensialis 


\section{PENDAHULUAN}

Film memiliki kekuatan dan kemampuan yang mumpuni dalam menjangkau berbagai macam segmen sosial. Hal tersebut kemudian menimbulkan asumsi dan opini bahwa film memiliki potensi untuk memengaruhi penonton. Penonton yang menyimak film dengan saksama dan/atau bahkan menonton sebuah film berkali-kali secara intens, secara tidak sadar akan menerima perspektif dan ideologi baru yang terdapat dalam film yang disaksikan tersebut secara halus dan efektif. Sehingga, perspektif dan ideologi dalam film tersebut dapat dicerna dan mengkristal dalam benak penonton. Film memiliki imbas tertentu terhadap masyarakat yang dapat menimbulkan pemahaman terbentuknya hubungan linier karena film memengaruhi dan membentuk masyarakat berdasarkan muatan-muatan pesan di dalamnya. Perlu disadari bahwa sesungguhnya film selalu merekam realitas yang tumbuh dan berkembang dalam masyarakat, dan kemudian memproyeksikannya ke atas layar (Irawanto, 1999). Graeme Turner (dalam Surwati, 2012) mengungkapkan bahwa film tidak hanya memindahkan realitas kehidupan ke layar tanpa mengubah realitasnya. Namun yang justru perlu diperhatikan adalah bahwa sebagai representasi dari realitas, film membentuk dan menghadirkan kembali realitas berdasarkan kode-kode, konvensi-konvensi, dan ideologi dari kebudayaannya. Dengan demikian, film mengupayakan fungsinya sebagai representasi realitas (Irawanto, 1999).

Sebagai rekaman realitas yang tumbuh dan berkembang dalam masyarakat dan kemudian memproyeksikannya ke atas layar (Sobur, 2006), film juga merupakan pembentuk konstruksi masyarakat akan suatu hal; salah satunya adalah tentang perempuan. Sosok perempuan merupakan sosok yang begitu memesona, dan masalah-masalah mengenai perempuan akan menarik untuk dibicarakan dan tidak habis dimakan zaman, tidak pula lekang dibahas tuntas. Persepsi masyarakat tentang perempuan mau tidak mau harus diakui sebagai hasil bentukan media massa, terutama sinema atau film. Berbagai penelitian mengangkat bahasan seputar persoalan gender dalam film, terutama ketimpangan posisi gender. Menurut Surwati (2012), Laura Mulvey menyatakan bahwa film merupakan alat untuk memenuhi kesenangan kaum lelaki. Perempuan hanyalah dijadikan sebagai pihak marjinal dan dimanfaatkan dalam opera-opera sabun yang tragis, film bergenre horor, dan film bertema seksual. Namun belakangan muncul film-film yang menjadikan perempuan sebagai tokoh utama. Perempuan bukan untuk kemudian diolok-olok, tetapi justru menjadi tokoh yang memiliki sosok sebagai pribadi yang utama. Ia menunjukkan eksistensinya di tengah-tengah tekanan dan himpitan dominasi rekan-rekannya yang notabene adalah kaum pria. Salah satunya adalah film berjudul “The Iron Lady” (20 ${ }^{\text {th }}$ Century Fox, 2011).

Penelitian ini membahas tentang sosok Margaret Thatcher dalam film "The Iron Lady", perempuan "penguasa” Inggris Raya, yang menjabat sebagai Perdana Menteri terlama (periode jabatan 1979-1990). Justru karena ia adalah seorang perempuan, ia mampu menjadi "penyelamat Inggris Raya" -the woman who saved great britain- bahkan sampai detik ini, setelah beliau tidak lagi menjabat, setelah beliau meninggal. Inggris Raya tetap berdiri tegak menantang krisis dan mengatasi resesi karena kekuatan, kecerdasan, dan cita rasa seorang perempuan. Di tengah himpitan dan dominasi rekan-rekan parlemen, yang ketika itu semuanya laki-laki dan hanya Thatcher yang perempuan, Thatcher mampu menyejajarkan posisinya meskipun banyak cemoohan, keraguan, dan ketidakpercayaan akan kemampuannya yang adalah seorang perempuan, mengemban tugas dan tanggung jawab sebagai politisi dan negarawan. Ibu, yang mampu mengawal, menjaga dan mengasuh negara. Ia bahkan lebih kuat, lebih tegar, dan lebih gagah daripada para ayah.

\section{Rumusan Masalah dalam Penelitian}

Banyak film yang meletakkan tokoh perempuan sebagai pelengkap semata. Perempuan dijadikan pemuas keinginan untuk sekadar dilihat polesan fisiknya tanpa mencitrakan sisi positif yang dimiliki perempuan yang justru merepresentasikan keutuhan pribadinya. Namun demikian, perjuangan 
perempuan untuk membuktikan eksistensinya tidaklah mudah dibendung. Film "The Iron Lady" dirilis bukan hanya untuk menghormati Margaret Thatcher, tetapi juga untuk menyadarkan perempuan. Perempuan memerlukan kekuatan yang dipompa keluar dari dalam diri untuk berani menyatakan suara, keluar dari keterbungkaman, dan menunjukkan keunggulannya, lewat cara-cara yang cerdas, cara-cara perempuan.

Berangkat dari konsepsi yang telah diuraikan, perumusan masalah utama dalam penelitian ini adalah: bagaimana perempuan direpresentasikan dalam film "The Iron Lady" serta bagaimana simbolsimbol atau nilai-nilai perempuan seharusnya direpresentasikan. Rumusan masalah utama penelitian kemudian dikembangkan menjadi subpertanyaan berikut: (1) penanda apa yang digunakan dalam mempresentasikan kekuatan perempuan dan (2) bagaimana kekuatan perempuan ditandai dalam film "The Iron Lady".

\section{Teori Semiotika (Semiologi) Roland Barthes atas Mitos}

Pendekatan semiotik Roland Barthes terhadap wacana terarah secara khusus kepada mitos (myth). Mitos dipahami sebagai sebuah tipe tuturan. Barthes memahami wacana sebagai tuturan (parole). Sehingga dapat disimpulkan bahwa mitos hanya merupakan sebuah tipe wacana, yang keberadaannya dikontrol dalam kerangka kultural dan merupakan hasil refleksivitas yang terbalik. Seperti yang telah dituturkan oleh Cobley dan Jansz (Sobur, 2006), bahwa dalam setiap esainya, Barthes membahas fenomena keseharian yang luput dari keseharian, yang konsep utamanya adalah bahwa konotasi yang terkandung dalam mitologi biasanya merupakan hasil konstruksi yang cermat.

Satu hal yang ditekankan oleh Barthes dalam kajiannya yaitu tentang tanda dan peran pembaca (reader) yang memunculkan sebuah sistem yang disebut sistem pemaknaan tataran ke-dua, yang dibangun di atas sistem lain yang telah ada sebelumnya. Sistem ke-dua oleh Barthes disebut dengan konotatif. Dalam konsep Barthes tanda konotatif tidak sekadar memiliki makna tambahan namun juga mengandung kedua bagian tanda denotatif yang melandasi keberadaannya. Gambar 1 menunjukkan peta tanda Roland Barthes.

\begin{tabular}{|c|c|}
\hline $\begin{array}{c}\text { 1. signifier } \\
\text { (penanda) }\end{array}$ & $\begin{array}{c}\text { 2. signified } \\
\text { (petanda) }\end{array}$ \\
\hline 3. denotative sign (tanda denotatif) & \multicolumn{2}{|c|}{} \\
\hline $\begin{array}{l}\text { 4. CONNOTATIVE SIGNIFIER } \\
\text { (PENANDA KONOTATIF) }\end{array}$ & $\begin{array}{l}\text { 5. CONNOTATIVE SIGNIFIED } \\
\text { (PETANDA KONOTATIF) }\end{array}$ \\
\hline \multicolumn{2}{|c|}{ 6. CONNOTATIVE SIGN (TANDA KONOTATIF) } \\
\hline
\end{tabular}

Gambar 1 Peta Tanda Roland Barthes

(Sumber: Cobley \& Jansz dalam Sobur, 2006:69)

Dalam kerangka Barthes konotasi identik dengan operasi ideologi, yang disebut sebagai mitos, dan berfungsi untuk mengungkapkan dan memberikan pembenaran bagi nilai-nilai dominan yang berlaku dalam suatu periode tertentu. Seperti halnya Marx, Barthes juga memahami ideologi sebagai kesadaran palsu yang membuat orang hidup di dalam dunia yang imajiner dan ideal meski realitas hidupnya yang sesungguhnya tidaklah demikian. Ideologi ada selama kebudayaan ada. Kebudayaan mewujudkan dirinya dalam teks-teks dan, dengan demikian, ideologi pun mewujudkan dirinya melalui berbagai kode yang merembes masuk dalam teks dalam bentuk penanda-penanda penting, seperti tokoh, latar, sudut pandang, dan lain-lain (Budiman dalam Sobur, 2006). 
Pendekatan semiotik menekankan pandangannya pada bentukan dan makna yang digunakan individu dalam konteks budaya untuk memproduksi maknanya. Ini berarti bahwa budaya memegang peranan penting dalam mengubah pengggunaan bahasa. Penggunaan dan penerimaan bahasa yang terkait dengan social agreement (kesepakatan sosial) inilah yang kemudian menentukan pemaknaan atas realitas yang ada yang direpresentasikan oleh tanda-tanda yang telah disepakati bersama. Semiotika menggunakan istilah tanda untuk menjelaskan bagaimana makna atau pemaknaan diproduksi secara sosial. Beberapa ciri yang dimiliki tanda, yaitu: (1) sebuah tanda memiliki bentuk fisik, yang disebut signifier (penanda) seperti model potongan rambut atau lampu lalu lintas; (2) sebuah tanda mengacu kepada sesuatu selain dirinya, yang disebut signified (pertanda/yang ditandai); hal ini menekankan pada sebuah konsep yang dimaksud, bukan mengacu pada hal nyata yang ada di dunia; (3) semiotika menekankan bahwa persepsi tentang realitas adalah dibentuk dan dikonstruksi sendiri oleh kata dan tanda yang digunakan dalam beragam konteks sosial (Branston \& Stafford, 2010).

\section{METODE}

Penelitian ini menggunakan paradigma kritikal. Paradigma kritikal mempunyai tujuan penelitian untuk membuka, memindahkan dan/atau membuang keyakinan dan ide keliru tentang masyarakat dan realitas sosial. Ide-ide keliru itu antara lain keyakinan akan adanya dunia yang objektif, kebenaran umum, segala sesuatu yang dapat diukur, dan juga anggapan bahwa semua makhluk hidup termasuk manusia memiliki kedudukan sama dalam dunia, mendapat pengaruh yang sama, dan dapat dicari keseragamannya (Poerwandari, 2001). Paradigma kritikal juga justru mengatakan bahwa dunia merupakan hal kompleks. Realitas sosial berada dalam ketegangan dan kontradiksi: posisi atau kelompok dengan kelompok lain berbeda-beda, dan ada pihak yang mengalami eksploitasi sementara pihak lain memanfaatkan, menekan, mengeksploitasi. Dengan keyakinan itu pendekatan kritikal berkembang dan banyak digunakan dalam berbagai kajian yang mempelajari distribusi kekuatan yang tidak seimbang, yang menguntungkan sebagian pihak dan sangat merugikan pihak lain. Termasuk di dalamnya adalah penelitian mengenai kelompok miskin dan marjinal, penelitian tentang kelas tersubordinat, dan penelitian tentang perempuan (Poerwandari, 2001).

Penelitian menggunakan jenis analisis paradigmatik Claude Levi-Strauss dalam Berger (2000) yang mengemukakan bahwa analisis paradigmatik teks memperlihatkan makna yang laten, yang di dalamnya struktur laten berisi teks tersebut bicara tentang apa. Dengan kata lain, ketika menggunakan pendekatan paradigmatik, penelitian tidak terlalu menaruh perhatian dengan apa yang dikerjakan karakter, tetapi lebih kepada apa yang dimaksudkan. Penelitian ini menggunakan metode analisis semiotika sebagai metode analisis dalam pemaknaan tanda dalam level naskah. Menurut Berger (2000), semiotika menaruh perhatian pada bagaimana makna diciptakan dan disampaikan melalui teks dan khususnya melalui narasi (cerita), yang fokus perhatiannya adalah tanda yang ditemukan dalam teks. Tanda dapat dipahami sebagai kombinasi dari penanda dan petanda.

Metode penelitian ini mengkhususkan pada analisis semiotika Roland Barthes untuk mengungkapkan hal yang ada di balik tanda atau sign sebuah teks. Penelitian semiotik merupakan salah satu bentuk analisis teks media yang bersifat kualitatif. Metode pengumpulan data berdasarkan analisis semiotika teks Roland Barthes yang berpendapat bahwa bahasa adalah sebuah sistem tanda yang mencerminkan beragam asumsi dari suatu masyarakat tertentu dalam waktu tertentu. Roland Barthes mengembangkan dua tingkatan pertandaan yang memungkinkan untuk dihasilkannya makna yang juga bertingkat-tingkat, yaitu tingkat denotasi (denotation) dan konotasi (connotation). Denotasi adalah tingkat pertandaan yang menjelaskan hubungan antara penanda dan petanda, atau antara tanda dan rujukannya pada realitas, yang menghasilkan makna yang eksplisit, langsung, dan pasti. Konotasi 
adalah tingkat pertandaan yang menjelaskan hubungan antara penanda dan petanda, yang di dalamnya beroperasi makna yang tidak eksplisit, tidak langsung, dan tidak pasti. Sedangkan mitos adalah pengkodean makna dan nilai-nilai sosial (yang sebetulnya arbitrer atau konotatif) (Piliang, 2003).

Signifikasi tahap pertama merupakan hubungan antara signifier (ekspresi) dan signified (isi) di dalam sebuah tanda terhadap realitas eksternal. Barthes menyebutnya sebagai denotasi, yaitu makna paling nyata dari tanda. Konotasi adalah istilah yang digunakan untuk menunjukkan signifikasi tahap kedua. Hal ini menggambarkan interaksi yang terjadi ketika tanda bertemu dengan perasaan atau emosi dari pembaca serta nilai-nilai dari kebudayaannya.

\title{
HASIL DAN PEMBAHASAN
}

\section{Keterbungkaman Perempuan}

Masalah subordinasi wanita dan dominasi patriarki sejalan dengan sebuah teori mengenai terbungkamnya sebuah kelompok karena ada kuasa yang lebih dominan yang datang dari kelompok lain. Teori ini disebut sebagai the muted group theory. Teori ini berfokus pada keberadaan kelompok minoritas atau subordinat sebagai kelompok yang terbungkam atau terbisukan, yang tak dapat menyuarakan kepentingan karena disepelekan bahkan dianggap tidak ada. Kelompok ini merasa tak punya kuasa sebab kekuasaan dipegang oleh kelompok yang dominan. Di tengah dominasi kelompok yang berkuasa kelompok ini memilih untuk diam atau bungkam, sehingga mereka menjadi kelompok yang terabaikan dan tak terlihat. Hal ini sebagaimana dikatakan oleh Edwin Ardener (Griffin, 2006:495):

\begin{abstract}
"Mutedness is due to the lack of power which besets any group that occupies the low end of the totem pole. People with little clout have trouble giving voice to their perceptions. The muted structures are there, but cannot be realized in the language of the dominant structure. As a result, they are overlooked, muffled, and rendered invisible - mere black holes in someone else's universe."
\end{abstract}

Cheris Kramarae menyatakan bahwa di dalam beberapa budaya tertentu, terbisukannya sebuah kelompok adalah akibat struktur bahasanya yang tidak memberi peluang yang sama bagi semua pembicara untuk memberi kontribusi dalam formulasi pembentukan kata-kata dan norma yang berlaku. Wanita merupakan salah satu kelompok yang tidak mendapatkan kesempatan itu karena bahasa diciptakan oleh laki-laki. Atau seperti yang dituliskan dalam West dan Turner (2010:477):

"The language of particular culture does not serve all its speakers equally, for not all speakers contribute in an equal fashion to its fornulation. Women (and members of other subordinate groups) are not as free or as able as men are to say what they wish, and when, and where they wish, because the words and the norms for their use have been formulated by the dominant group, men."

Teradaptasi dengan keji dalam masyarakat laki-laki serta terdominasi oleh patriarki, wanita sering terpaksa menyesuaikan pola kebiasaannya sampai betul-betul sesuai di mata laki-laki. Keterbatasan bahasa tidak hanya membatasi wanita dalam mengeluarkan pendapat dari pemikirannya,tetapi juga secara tidak adil justru direpresentasikan menurut perspektif laki-laki. Shirley Ardener (West \& Turner, 2010) menyatakan bahwa kebisuan wanita adalah akibat dari ketulian telinga laki-laki. Meskipun wanita berbicara, tetap saja perkataannya membentur telinga yang tuli. Hal itu mengakibatkan wanita akhirnya menyerah dan mulai berhenti untuk menyuarakan suara mereka, bahkan mulai berhenti juga untuk berpikir bahwa mereka memiliki hak pasti untuk mengeluarkan pendapat. 
Menurut Kramarae (West \& Turner, 2010:481), ada tiga asumsi penting dalam teori Muted Group ini. Pertama, wanita merasa bahwa dunia mereka berbeda dengan laki-laki karena dasar pengalaman dan aktivitas pekerjaan yang berbeda. Kedua, dominasi politik laki-laki membuat sistem persepsi laki-laki pun dianggap dominan, sehingga menghalangi kebebasan berpekspresi wanita. Ketiga, dalam keikutsertaannya berpartisipasi di masyarakat wanita kemudian harus bertransformasi model atau gayanya sendiri dan menukarnya dengan sistem berekspresi laki-laki.

Pembisuan terhadap wanita tidak hanya melalui kekuatan perkataan, tetapi juga dengan cara membentuk dan mengontrol pembicaraan pihak lawan. Pembisuan ini akan terus terjadi dalam lingkungan sosial selama ada pihak yang berkuasa penuh, dan ada pihak yang tidak punya kuasa apapun. Pembisuan ini terwujud dalam berbagai bentuk. Contoh yang paling jelas adalah ritual setelah menikah: wanita akan cenderung memakai nama suaminya sebagai identitasnya yang baru. Dominasi pria sepertinya menjadi hal yang sulitditembus. Akhirnya wanita berusaha memahami laki-laki sebagai individu dan kemudian membandingkannya dengan dirinya sendiri, sehingga ia dapat membuat identifikasi sempurna atasnya. Ia mengerjakan rencana-rencananya dan merawat yang dimilikinya dengan cara yang tidak dapat ditiru oleh laki-laki. Ia bekerja menurut caranya dan dengan gayanya sendiri.

Wanita yang tidak bisa survive di tengah pergulatan dan persaingan dengan laki-laki akan dengan mudah tersingkir. Ada yang harus berubah dari seorang wanita supaya dapat didengar, diperhatikan, dan dihargai oleh lingkungan pekerjaannya. Seperti yang dikatakan Kramarae (Griffin, 2006:499), "In order to participate in society women must transform their own models in terms of the received male system of expression."

Ketika adegan ketika pertama kali Thatcher menginjakkan kakinya di gedung parlemen, seorang rekan politiknya mengatakan: "Me thinks the right honorable lady doth screech too much! If she wants us to take her seriously, she must learn to calm down." Percobaan pembungkaman dan penindasan tersebut dijawab secara cantik oleh Thatcher dengan dengan kalimat: "If the right honorable gentlemen could perhaps attend more closely to what I'm saying, rather than how I'm saying it, he may receive a valuable education in spite of himself."

Tidak hanya dengan kepercayaan diri dalam menyatakan sikap melalui pernyataan dalam kalimat yang diiucapkan oleh Thatcher, dia juga kemudian mengubah penampilannya menjadi lebih dewasa. Thatcher meyakini dan menyadari kekuatannya tidak lebih lemah dari rekan prianya, dia setara, bahkan lebih kuat dalam banyak hal. Akan tetapi, dia menyadari bahwa ada cara-cara yang harus dia lakukan supaya dia didengar, diperhatikan, bahkan dituruti oleh rekan prianya. Dia tahu dengan kecerdasannya, dia dapat menaklukkan mereka.

\section{Eksistensi Perempuan}

Salah satu upaya wanita agar dapat mengatasi ketidakseimbangan dalam dunia laki-laki adalah dengan menggunakan kecantikan. Beberapa aktivis berpendapat bahwa mitos kecantikan yang dipercaya dalam dunia laki-laki ini sebenarnya memberikan keuntungan bagi wanita untuk bisa menjadikan wanita bukan sebagai "Liyan” melainkan justru sebagai "Diri”. Kecantikan bisa digunakan oleh wanita untuk mendominasi laki-laki melalui jiwa dinamisnya, dan menerima kekaguman dari mereka dengan kesombongan, sehingga wanita tak perlu merasa menjadi mangsa dalam pelukan laki-laki (Beauvoir, 2004).

Dalam semua segi wanita harus menjadi seperti laki-laki, berkompetisi layaknya laki-laki, melakukan apapun yang layak dilakukan laki-laki, dan berpikir seperti laki-laki. Namun demi didengar dan tidak lagi terbungkam, para wanita harus terlebih dahulu mengalah untuk menang. Dalam artian sebagai others, wanita harus mengubah dirinya sesuai dengan keinginan "kelompok" selfs; menjadi others sesempurna yang diinginkan oleh self. Sehingga dengan demikian wanita lambat laun berproses 
menjadi self. Wanita menjadi bukan lagi sosok yang dipandang sebelah mata, tetapi bertransformasi menjadi sosok yang begitu digandrungi dan dibutuhkan oleh semua pihak.

Bagi Sartre (Tong, 2006) eksistensi mendahului esensi. Dengan kata lain, manusia ada hanya sebagai organisme hidup yang amorfus (tidak memiliki bentuk yang ajeg), hingga ia menciptakan identitas yang terpisah dan esensial bagi dirisendiri melalui tindakan yang sadar, melalui pilihan dan keputusan, menegaskan kembali tujuan dan proyek lama, serta menegakkan tujuan dan proyek yang baru. Dengan mengadopsi bahasa ontologis dan bahasa etis eksistensialisme, Beauvoir mengemukakan bahwa laki-laki dinamai sang "Diri", dan perempuan dinamakan "Liyan". Jika Liyan adalah ancaman bagi sang Diri, perempuan adalah ancaman bagi laki-laki. Karena itu jika laki-laki ingin tetap bebas, ia harus bisa mensubordinasi perempuan terhadap dirinya. Jika wanita ingin menghentikan kondisinya sebagai jenis kelamin yang kedua (Liyan), wanita harus dapat mengatasi kekuatan-kekuatan dari lingkungan. Wanita harus mempunyai pendapat dan cara seperti juga laki-laki.

Dalam proses menuju transendensi, menurut Beauvoir (Tong, 2006:274), ada tiga strategi yang dapat dilakukan oleh wanita. Pertama, wanita harus bekerja. Tentu saja Beauvoir sendiri menyadari bahwa bekerja dalam kapitalisme yang patriarkal bersifat opresif dan eksploitatif. Namun betapapun kerasnya dan melelahkannya pekerjaan wanita, hal tersebut akan memberikan kesempatan dan kemungkinan bagi wanita, yang jika tidak dilakukan, mereka akan kehilangan kesempatan itu sama sekali. Dengan bekerja di luar rumah bersama laki-laki, maka wanita dapat merebut kembali transendensinya. Wanita akan secara konkret menegaskan statusnya sebagai subjek, sebagai seorang yang secara aktif menentukan arah nasibnya. Kedua, wanita dapat menjadi seorang intelektual. Kegiatan intelektual adalah kegiatan ketika seseorang berpikir, melihat, dan mendefinisi, bukan sebaliknya. Ketiga, wanita dapat bekerja untuk mencapai transformasi sosialis masyarakat. Salah satu kunci bagi pembebasan perempuan adalah kekuatan ekonomi, suatu poin yang ditekankan Beauvoir dalam setiap diskusi mengenai perempuan mandiri. Lingkungan tentu saja akan membatasi usaha mereka untuk mendefinisikan diri. Maka jika wanita ingin mewujudkan semua yang diinginkannnya, ia harus menciptakan masyarakat yang akan menyediakan dukungan material untuk mentransendensikan batasan yang melingkarinya sekarang.

Akhirnya untuk mentransendensikan batasan-batasannya, wanita dapat menolak menginternalisasi ke-liyan-annya, yaitu dengan mengidentifikasi dirinya melalui pandangan kelompok dominan, dalam masyarakat. Ketika wanita terpanggil untuk melakukan tindakan konkret, ketika mereka menyadari ketertarikan mereka dalam impian-impian yang terencana, mereka sama hebat dan beraninya dengan laki-laki.Yang menghalanginya hanyalah karena wanita tidak memiliki genggaman atas dunia laki-laki sebab pengalaman tidak mengajarkan mereka menggunakan nalar dan teknik, selain kesempatan untuk menggunakannya sangatlah kecil. Sehingga, seolah-olah, wanita menjadi tidak mampu melakukan hal yang dilakukan pria.

Tiap eksistensi manusia melibatkan transendensi dan imanensi secara bersamaan. Untuk melangkah ke depan, tiap eksistensi harus dilestarikan. Demi memperluas eksistensi ke masa depan, hal tersebut harus terintegrasi dengan masa lalu, dan ketika berkomunikasi dengan orang lain, eksistensi tersebut harus menemukan konfirmasi diri. Wanita memenuhi takdir fisik mereka dengan menjadi seorang ibu; menjadi ibu adalah panggilan alam karena seluruh struktur organis mereka diadaptasikan untuk kelanjutan spesiesnya (Beauvoir, 2004). Menurut tradisi, generasi baru yang harus memastikan kebebasan sejati wanita, yang bahwa mereka bebas untuk mengabdikan diri pada tujuantujuan akhir yang lain. Jika sebagai istri seorang wanita merasa tidak lagi menjadi sosok individu yang komplit, ia menjadi seorang ibu. Karena kemudian, melalui anak ia akan bisa menemukan jati dirinya secara seksual dan sosial. Meskipun untuk menemukannya, perjuangan sebagai proses menuju kebaruan tersebut tidak mudah untuk ditapaki dan terasa melelahkan.

Wanita yang beremansipasi adalah wanita yang ingin aktif dan bertanggungjawab akan sesuatu, serta menolak pasivitas yang biasa ditekankan laki-laki padanya. Mereka akan menempatkan 
tubuh di atas semangat, dan kebijaksanaan di atas ketegasan. Wanita modern lebih kompromis demi mengejar transformasi menjadi self. Mereka menerima nilai-nilai maskulin, bangga akan dirinya sendiri untuk berpikir, mengambil tindakan, bekerja, dan mencipta dalam term yang sama dengan lakilaki. Daripada berusaha mengatakan sesuatu yang menyatakan bahwa mereka mempunyai nilai penting yang kecil, wanita justru mendeklarasikan dirinya sebagai sosok yang patut diperhitungkan.

Thatcher kemudian mengubah penampilannya demi mendapatkan pengakuan akan kemampuan politisnya, akan kecerdasannya memikirkan dan memutuskan strategi-strategi kenegaraan. Salah satu hal yang juga dia perlihatkan ketika mengundang Menteri luar Negeri USA untuk datang dan membicarakan tentang persekutuan untuk "Falkland Island" di Argentina. Ketika menteri luar negeri itu datang, ia disambut secara baikdan hangat. Sebelum memastikan bahwa menteri tersebut berada di pihaknya, Thatcher mempersuasinya dengan perkataan: "Let your mother, care about you." Dalam teks tersebut Thatcher menyiratkan maksud bahwa apapun yang terjadi nanti, jika USA mau berada di pihak Inggris Raya, kehidupan mereka akan tenteram, tidak kekurangan apapun, karena ibunyalah yang memikirkan sekaligus menjalankan strateginya.

Wanita yang berdandan-berpenampilan baik termasuk dalam kategori berdandan-adalah wanita yang sedang berusaha untuk mendapatkan pengakuan yang absolut terhadap kecantikan, keanggunan, cita rasa, dan dirinya sendiri sebagai manusia yang utuh (Beauvoir, 2004). Meskipun memang tidak dapat dipungkiri bahwa kehidupan masyarakat yang menuntutnya memamerkan yang dia miliki baik secara fisik maupun secara psikis. Wanita tahu persis bahwa ketika ia diperhatikan, ia tidak akan dianggap terpisah dari penampilannya. Ia dinilai, dihormati, dan diinginkan melalui penampilannya. Wanita harus selalu menjaga kerapihannya karena masyarakat tidak memaafkan kecerobohan melekat pada dirinya. Namun bukan karena pendapat orang kemudian mereka mau menyediakan waktu dan perhatian pada penampilannya, ia justru menjaga dan melakukan semuanya itu untuk kepuasannya sendiri. Ia dapat menghargai dirinya dengan kesesuaian seluruh masa kini dan masa lalunya, hanya dengan menggabungkan kehidupan yang ia tunjukkan untuk dirinya sendiri.

Laki-laki ingin wanita menjadi objek, maka wanita pun memperlakukan dirinya sebagai objek. Bersamaan dengan bertingkah laku sebagai objek, wanita sedang melakukan suatu aktivitas bebas. Di sanalah letak pernyataan dirinya, yang bahwa makin pasif, sesungguhnya ia makin sadar terkadang kenyataan bahwa dalam menyerahkan dirinya pada laki-laki, pandangan dan penilaiannya sudah cukup untuk membuat laki-laki sadar bahwa wanita bukanlah mangsa. Wanita justru sosok yang dengan sadar berjuang untuk mencapai tingkat yang dicapai oleh pria. Pria kemudian membantunya memuja kemuliaan dan kesombongan, dan sebagai gantinya, wanita memanfaatkan kekuatan tipu daya kelemahlembutan untuk melawan laki-laki. Dengan itu ia meraih kesenangan karena perjuangannya tidak sia-sia. Kemudian oleh karena hal tersebut, mereka menuju dunia yang memandang wanita pada posisi yang tidak dapat lagi dipandang sebelah mata.

Menurut Beauvoir (2004), wanita intelektual mengetahui bahwa ia tengah menawarkan dirinya, ia mengetahui bahwa ia adalah makhluk yang sadar, sebuah subjek. Wanita intelektual akan mencoba semua cara dengan lebih keraskarena ia takut gagal. Wanita intelektual (Beauvoir, 2004), segera setelah ia merasa gelisah, ia menjadi jengkel dengan kerendahannya, ia ingin melakukan pembalasan dengan turut bermain dengan senjata maskulin. Ia berbicara, bukan mendengar, ia menunjukkan pikiran-pikiran yang tajam, ia melawan laki-laki, bukan lagi berdamai dengan mereka. Ia mencoba mendapatkan yang terbaik dari laki-laki untuk memperoleh kemenangan yang mengagumkan.

Dunia perkantoran, menurut Beauvoir (2004) adalah dunia yang syarat dengan isyarat, dunia perilaku tanpa tujuan, dunia yang secara esensial adalah maskulin. Namun di dunia itulah, perempuan justru menancapkan sepak terjangnya secara lebih dalam pada sisi realitas-karena figur perempuan yang bekerja adalah aset pribadi yang nyata. Dalam pengejaran yang konkret atas tujuan tersebut, perusahan 'laki-laki' membuat suatu perangkap, bahwa mereka berharap perempuan akan terjebak 
dalam pengelakan-pengelakan, perempuan dianggap akan membiarkan dirinya sendiri ditekan dan tenggelam oleh karier dan medan pertempurannya di lingkungan pekerjaan. Hal itu dipandang sebagai hal-hal yang akan menggiring perempuan menjadi sosok yang tinggi hati, dan selalu merasa penting. Perangkap tersebut ternyata tidak menjebak perempuan; justru perempuan kemudian tidak mengidentifikasikan dirinya dengan anggapan-anggapan tersebut. Perempuan tidak mencari pelarian dalam kebanggaannya atas ambiguitas posisinya tersebut; ia tidak bersembunyi di balik topeng harga diri manusia; ia justru mengungkapkan emosi, pemikiran-pemikiran, dan reaksi spontanitasnya secara lebih jujur. Ketika laki-laki merasa menang, ternyata mereka dikalahkan oleh keangkuhan mereka sendiri. Ketika laki-laki mendiskusikan yang disebut sebagai gagasan-gagasan umum, kata-kata, formula-formula, dan rangkaian pemikiran yang akan ditemukan hanya pada kolom-kolom kertas kerja atau dalam kerja-kerja teknisnya, perempuan menampilkan diri sebagai sosok yang unggul dengan cara mengemukakan pendapat-tidak hanya di atas kertas kerja-berdasarkan pengalaman yang mungkin lebih terbatas, tetapi sangat nyata.

Wanita yang patut diperhitungkan, yang dipandang sebagai diri, sebagai seseorang adalah wanita yang mampu menjadi superwoman. Ia tidak hanya berhasil dan menang dalam pergumulannya di lingkungan kerja, tetapi juga berhasil menjadi seorang ratu di rumah tangganya, di lingkungan keluarganya. Kaum laki-laki sudah mulai menyerahkan dirinya pada status baru yang dimiliki oleh perempuan (Beauvoir, 2004). Perempuan yang bekerja justru memegang kukuh dan lebih menunjukkan rasa bangga akan feminitasnya. Perempuan yang bekerja justru semakin memancarkan pesonanya. Perempuan yang mandiri, yang memiliki otonomi secara finansial menjadi sosok yang kemudian memiliki hak-hak istimewa, sama seperti akses dan hak-hak yang dimiliki oleh laki-laki. Keberhasilan ini telah menunjukkan kemajuan atas proses transformasi perempuan dari other menjadi self.

Setiap wanita harus menggariskan kehidupannya sendiri. Situasi hukum, politik, ekonomi, sosial, dan budaya menghambat wanita. Namun tidak satupun dari penghambat itu yang dapat memenjarakan wanita secara total. Menurut Carol Ascher (Tong, 2006:282), "manusia membuat keputusan untuk melepaskan diri dari atau bertahan dengan harus menghadapi tingkat hambatan yang berbeda-beda. Pada kondisi tertentu tidak ada keputusan positif yang mungkin diambil, meskipun demikian, keputusan tetap diambil, dan setiap individu harus bertanggung jawab atas keputusan tersebut."

\section{Representasi Perempuan}

Representasi menunjuk pada bagaimana seseorang, satu kelompok, gagasan atau pendapat tertentu ditampilkan dalam pemberitaan. Ada dua hal penting dalam representasi. Pertama, apakah seseorang, kelompok, atau gagasan tersebut ditampilkan sebagaimana mestinya. Ini mengacu pada apakah seseorang atau kelompok itu diberitakan apa adanya, ataukah diburukkan. Penggambaran yang tampil bisa jadi adalah penggambaran yang buruk dan cenderung memarjinalkan seseorang atau kelompok tertentu. Di sini hanya citra yang buruk saja yang ditampilkan sementara citra atau sisi yang baik luput dari pemberitaan. Kedua, bagaimana representasi tersebut ditampilkan. Dengan kata lain, kalimat, aksentuasi, dan bantuan foto macam apa seseorang, kelompok, atau gagasan tersebut ditampilkan dalam pemberitaan kepada khalayak.

Persoalan utama dalam representasi adalah bagaimana realitas atau objek tersebut ditampilkan. Menurut John Fiske (Surwati, 2012) paling tidak ada tiga proses dalam menampilkan objek, peristiwa, gagasan, kelompok, atau seseorang. Pada level pertama adalah peristiwa yang ditandai sebagai realitas. Dalam bahasa gambar ini umumnya berhubungan dengan aspek seperti pakaian, lingkungan, ucapan, dan ekspresi. Pada level kedua, ketika seseorang memandang sesuatu sebagai realitas dan bagaimana realitas itu digambarkan. Yang digunakan disini adalah perangkat secara teknis, misalnya kata atau kalimat. Ini membawa makna tertentu ketika diterima oleh khalayak. Pada level ketiga, bagaimana peristiwa tersebut diorganisasikan ke dalam konvensi-konvensi yang 
diterima secara ideologis dan bagaimana kode-kode representasi dihubungakan dan diorganisasikan ke dalam koherensi sosial seperti kelas sosial, atau kepercayaan dominan yang ada dalam masyarakat.

Dari film "The Iron Lady", Thatcher menyatakan suara dan pendapat-pendapatnya dengan banyak kiasan. Dia mengubah penampilannya sedemikian rupa untuk menunjukkan kelasnya. Gaun bermotif houndstooth, potongan rambut dengan set di bawah telinga, dan perhiasan mutiara (signifier), merepresentasikan wanita kelas atas dan intelektual Inggris (signified).

\section{SIMPULAN}

Perempuan harus secara sadar dan berani menyatakan suara dengan kepercayaan diri yang sungguh, tidak hanya secara fisik, tetapi juga cara mereka menyampaikan apa yang ada pada pikirannya. Mendobrak ketertindasan dan keterbungkamannya dengan berbagai cara, namun demi mendapatkan eksistensi di tengah rekan pria yang mendominasi, perempuan sebaiknya menggunakan keperempuanannya, kecerdasan, kekuatan, dan cita rasanya, beberapa dari sekian banyak hal yang tidak dimiliki pria. Representasi perempuan digambarkan secara sempurna oleh Thatcher dalam film "The Iron Lady" dengan cara pemilihan kalimat yang kuatdan penampilan fisik yang mencengankan, sehingga perempuan terdefinisikan secara sempurna.

\section{DAFTAR PUSTAKA}

$20^{\text {th }}$ Century Fox. (2011). The Iron Lady. Directed by Phyllida Lloyd. US: Fox Entertainment Group.

Andhika Martha W. (2013, Februari). Representasi Perempuan dalam Film Horor Indonesia. Media Commonline, 1(2). Diakses dari http://journal.unair.ac.id/article_4604_media137_category8.html

Beauvoir, S de.(2004). Second Sex: Kehidupan Perempuan. Surabaya: Pustaka Promethea.

Berger, A. A. (2000). Teknik-teknik Analisis Media. Yogyakarta: Universitas Atma Jaya Yogyakarta.

Branston, G., and Stafford, R. (2010). The Media Student’s Book, 5th Edition. Oxon: Routledge.

Griffin, E.M. (2006). A First Look At Communication Theory, 6th Edition.New York: McGraww-Hill.

Irawanto, B. (1999). Film, Ideologi dan Militer; Hegemoni Militer dalam Sinema Indonesia.Yogyakarta: Media Pressindo.

Piliang, Y. A.(2003). Hipersemiotik: Tafsir Cultural Studies atas Matinya Makna. Yogyakarta: Jalasutra.

Poerwandari, E. K. (2001). Pendekatan Kualitatif dalam Penelitian Psikologi. Jakarta: Lembaga Pengembangan Sarana Pengukuran dan Pendidikan Psikologi, Fakultas Psikologi, Universitas Indonesia.

Sobur, A. (2006). Semiotika Komunikasi. Bandung: Remaja Rosdakarya. 
Surwati, C. H. D. (2012, Januari). Konstruksi Feminisme dalam Film Indonesia (Analisis Wacana Kritis). Jurnal Komunikasi Massa, 5(1).

Tong, R. P. (2006). Feminist Thought: Pengantar Paling Komprehensif pada Arus Utama Pemikiran Feminis. Yogyakarta: Jalasutra.

West, R., and Turner, L. H. (2010). Introducing Communication Theory: Analysis and Application,4th Edition. New York: McGraw-Hill. 